\title{
Factors that Influence Consumers' Future Purchase Intention
}

\author{
Bab Shah $^{1 *}$ iD $\mid$ Muhammad Asif Awan ${ }^{2}$ iD $\mid$ Amama Alvi $^{3}$ iD \\ Dr.Ghazala Tumio ${ }^{4}$ iD $\mid$ Nasir Ali $^{5}$ iD
}

\begin{abstract}
The main aim of this study is to examine the key factors that influence future purchase intention and shape the consumers' attitude towards brand social media pages. Data were collected through a questionnaire survey from Lahore city, Pakistan. A total number of 380 responses were collected from which 274 were analyzed by using structural equation modeling. The outcomes of the study shows that brand credibility, brand familiarity, and attitude towards brand social media page are the key factors of future purchase intention. Moreover, the study found a negative significant association of brand familiarity and e-wom with future purchase intention for the female group. The study further found that involvement is positively significantly associated with consumers' attitudes towards social media. So far; no study examines the factors of future purchase intention based on gender. This study contributes to explaining the inconsistent results between e-WOM and future purchase intention. Implication concerning offers for managerial brand marketers, firms, and research practices and directions for future research presented.
\end{abstract}

Keywords: Brand Credibility, Brand Familiarity, e-WOM, Future Purchase Intention, Involvement

\section{Author's Affiliation:}

Institution: Shaheed Benazir Bhutto University ${ }^{1} \mid$ University of veterinary and animal sciences $^{2-3-5} \mid$ Mehran University Institute of Science, Technology \& Development Pakistan ${ }^{4}$

Country: Pakistan

Corresponding Author's Email: *babshah75@gmail.com

The material presented by the author(s) does not necessarily portray the view point of the editors and the management of the ILMA University, Pakistan.

(Online) 2409-6520 (Print) 2414-8393 C2021, published by the ILMA University, Pakistan.

This is open access article under the @ (1) license. https://creativecommons.org/licenses/by/4.0/

Page $\mid 10$ 
IBT Journal of Business Studies (IBT-JBS) Volume 17 Issue 1, 2021

\section{1) INTRODUCTION}

Social media is a new medium for business, which has changed the way of consumers purchase products or services. Rapidly increasing, consumers start to purchase products or different services through e-commerce websites, instead of the physical store. As compared to the traditional way of shopping, the mode of online shopping offers many benefits, such as save time and money to go to that particular place to buy that product and there are no temporal and spatial limitations. Social media give a chance to brands or businesses to contribute and cooperate with potential customers, promote a sense of understanding with customers, moreover build a strong association with potential clients. (Mersey et al, 2010). Consumer purchasing is mostly placed on the virtual form such as pictures, images, quality information, and video clips of the goods, but no real experience is involved (Kolesar and Galbraith, 2000; Lohse and Spiller, 1998).

Hudson et al. (2016) proposed that when brands cooperate with followers through digital media by invitin g participation, solving problems, and replying to comments, customers have powerful relations with the brand having a sense of association, and therefore experiencing a high level of connection quality. Digital media is a simple use, and affordable, platform offering a straight connection to connect to consumers for a brand. It is crucial to identify the determinants affecting customers to connect with a brand on digital media platforms and the influence of involvement on digital media. Time has to change and communication media shift on digital platforms, it is also crucial for brands to know how participation on digital media platforms may affect the intention of consumers and their attitude. Previous researches have paid attention mainly to the Facebook circle, yet digital media is a wide area with lots of brands and customers being actively involved on various sites (Gummerus et al., 2012; Durukan et al., 2012). Aside from brand familiarity and online brand experience, information adoption and e-WOM has been found as a key determinant of online purchase behavior of consumer by prior studies (Park \& Stoel, 2005; Morgan-Thomas and Veloutsou, 2013).

The main objective of this study is to examine the key factors of future purchase intention. Second, find the association involvement of social media with consumers' future purchase intention and their attitude towards social media pages. In particular, this study aims to seek the answer to the following questions.

Q1: Which determinants of consumers' involvement influence the future purchase intention from a brand?

Q2: Which are key factors that influence the consumers' future purchase intention?

\section{2) LITERATURE REVIEW}

In this section, we discuss previous studies related to the factors that influence the attitude of consumers towards social media pages of brands and future purchase intention, and based on these studies we formulate the hypothesis for our study. Over time, approaches of information technology improved such as website, website 
design, internet security and functionalities, positive perception of consumers about electronic commerce are also increases, and environment of online shopping is transforming even more mature commercial channel. (Wen, Prybutok, \& Xu, 2011).

With the rapid increase of adoption of social media, it is essential to understand which factors influence the consumer's purchase intention. According to Turban et al. (2005), the online purchase intention of consumers is currently increasing at a very rapid pace and covering the traditional method of the buying process. This situation is leading to increasing the market entry of online sellers with new online brand familiarity (Brakus et al., 2009).

The research recommends that high quality of information on social media pages of brands allow consumers to acquire a better understanding of brand offerings acquire support from other consumers and become able to make better purchase decisions (Watts and Zhang, 2008). High quality of information is a good source to acquire facts related to specific services or goods (Barreda et al., 2015). Social media provides reliable, quick, credible, and updated information to consumers (Jang et al., (2012). According to Martins et al., (2019) study suggests the quality of information available on social media pages and websites of brands significantly influenced brand perception as trustworthy, which ultimately is the reason for an increase in purchasing.

In past, consumers gain information from friends and marketers. However, WOM of social media has become a great source of information in recent days (Alhidari et al., 2015). WOM of social media is factors that affect consumer's decision process of buying at different level (Mishra and Satish, 2016) this is due to advancement in technologies that allow consumers to obtain and share information at a place and time (Nam et al., 2020) and show that word of mouth has a significant direct impact on purchase intention of consumers (Jalilvand and Samiei., (2012). Brands need to focus on the significance of functional value as it is the most impactful element among social media WOM determinants (Park et al., 2021) and show that consumers who used WOM of social media to share and spread information of brands eventually lead to purchase intention (Park et al., 2021). Past studies state that credibility positively influences the ads on websites and social media pages of brands (Shareef et al., 2019; Saima and Khan, 2020). However, consumers are more involved in exploring the social media pages of the familiar brand as compare to the unfamiliar brand (Lenhart et al., 2010). The past studies recommend that online brand experience compares to online brand familiarity influence the purchase intentions of consumers (Esteban-Santos et al., 2016; Wang et al., 2017) and brand credibility can strengthen the association bond among firm and consumers as well as increases the consumers purchase intention (Jeng., 2016).

This recommends that different factors influenced consumers' purchase intention. However, these previous studies were conducted in the context of different contexts but the current study focused on the social media pages of brands and how consumers' purchase intention is shaped by involvement on these social media pages. Thus, consumers' purchase intention will be influenced by (brand credibility, brand familiarity, and information quality) through mediating effects 
of involvement. So, the following conceptual framework is developed (Figure 1).

\section{3) CONCEPTUAL FRAMEWORK AND HYOTHESIS FORMULATION}

The objective of this research paper is to examine the factors which influence the consumer's purchase intention and attitude through the involvement of social media pages of brands. We conceptualized and integrated the research model (see figure 1) used four independent constructs brand familiarity, brand credibility, information quality, and E-WOM shaped attitude and purchase intention (two dependent constructs) and how this relation mediates by the involvement of consumers.

\section{1) INFORMATION QUALITY}

Information quality defines as completeness, correctness, comprehensibility, clarity, Information system data output facility, and usefulness. Park \& Kim (2006) recommended that consumers place a high value on trustworthy online product information. Faced with the massive amount of uncertain reliability of information this is provided online, consumers give priority to information quality as well as also lack and availability of quality information will have an impact on shopping experiences of consumers and shopping intention for services and products online (Ghasemaghaei \& Hassanein, 2015). Jones \& Kim (2010) found that the information quality of the site significantly affects the intention of online shopping from the site. Prior researches have investigated credibility and information quality in a discussion forum on the Internet. Savolainen (2011) found the matter of credibility and information quality is increasing the significance, especially in the context of the World Wide Web. Studies argued that the sentiment of brand community on social media positively influences the involvement of consumers on the social media page of that brand (Habibi, et al., 2014; Christodoulides, et al., 2012). Thus, we formulate the next hypothesis is as follow:

H1: There is a positive significant association between information quality and Involvement.

\section{2) BRAND FAMILIARITY}

Alba and Hutchinson (1987) examined that brand familiarity act as the fundamental roots of information regarding a particular brand, which will be increased by or frequent exposure to the brand or accumulated experiences within a brand. Consumers are likely to consider the brand as recognizable when it starts to advertise the brand frequently on the media. Therefore, the brand which is a well-known brand is more known to customers as well as it is easier to recall and be familiar with as compared to an unknown brand that is not familiar or advertised (Kent and Allen, 1994). Brand familiarity plays a vital role in the perception of the consumers towards a brand or product and their intentions of purchase from the brand (Gefen, 2000; Laroche et al., 1996). Fen et al. (2012) examine the impact of quality, familiarity, and perception of store brands and their study found that purchase intention and perceived quality of store brand items are highly influenced by brand familiarity. Seock \& MacBride (2012) also determined that knowledge of the consumers and their familiarity with 
a brand is a key factor in forming their preferences and perceptions for a brand. In contradictory, Simonson (2015) considers that a brand's issue online is not much than offline because social media provides more information about the quality of the brands' product offline, via online reviews available on their pages. Therefore, the following research hypothesis is formulated;

H2a: Positive association exists between consumers' brand familiarity and involvement.

H2b: There is a significant positive association between consumer brand familiarity and the future purchase intention of consumers.

\section{3) BRAND CREDIBILITY}

Brand credibility can be studied from the source credibility research stream. Source credibility can be described as positive sender's attributes that affect the receiver message approval (Ohanian, 1990) or it is the believability of intentions of an entity (Erdem \& Swait, 2004). This sender could be a corporation (Keller, 2000), a real person or entity (Frieden, 1984), it will be the brand (Erdem \& Swait, 2004), or the character of the cartoon (Stafford, Stafford, \& Day, 2002). Source credibility includes attractiveness/likeableness expertise and trustworthiness. So the brand credibility is the name of characteristics of product information expressed by a brand and the brand has three features, i.e., attractiveness/likeableness expertise, and trustworthiness (Keller \& Aaker, 1998; Sternthal \& Craig, 1982). The brand credibility needed consumers to believe that the brand is very reliable and can be trusted (trustworthiness), it has skills (i.e., proficiency), and this brand is very committed (i.e., likeableness/attractiveness) to constantly distribute what it has been promised with their consumers (Erdem \& Swait, 2004). According to (Swait and Erdem, 2007) positive relationships exist between brand credibility and attitudes of consumers toward the brands and choice of the consumers. They recommended that the more brand credibility is, the higher will be the purchase intention of consumers for that brand. Thus, we hypothesize that:

H3a: There is a significant association between consumers' brand credibility and involvement.

H3b: There is a significant effect of consumers' brand credibility on brand future purchase intention.

\section{4) INVOLVEMENT}

Sherif and Cantril (1947) introduced that involvement as a construct has been expressed as a motivational, self-directed emotional condition of a particular consumer that reveals the personal significance of buying that particular product (Rothschild, 1984). Involvement has been depicting that it applies a significant influence over purchase decision processes of the consumers for products in general (e.g., Laurent and Kapferer, 1985a, Laurent and Kapferer, 1985b). According to prior studies certain determinants such as advertising attitudes, purchase intention, 
brand attitudes and online buying behaviors has a significant impact on involvement (Huang et al., 2010; Bosnjak et al., 2007; Yang, 2012). Hutter et al. (2013) investigated that how much the purchase decision-making process is influenced by digital media activities of brands and the consumer's involvement with the social media pages of the brand. They also perceived that the intensity of involvement with applications of digital media is a prominent sign of positive word of mouth and purchase intention. Accordingly to the all above prior research, we formulate hypotheses are as follow;

H4a: There is a positive significant association that exists between the involvement of consumers and their attitude towards a brand's social media presence.

H4b: There is a positive significant association that exists between the involvement of Consumers and their future purchase intention from the brand.

Ajzen $(1985,1991)$ proposed (TRA) Theory of Reasoned Action, which depicts that subjective norm and attitude toward an object are the main factors of intention to execute a certain behavior. The attitude that leads to a thing is famous as an individual's negative or positive assessment of an item as well as included silent belief of an individual.

According to (Gefen, Karahanna, \& Straub, 2003) trusting attitude has significantly affected online purchase intention. A recent study carried out by Schivinski \& Dabrowski (2016) found that the brand attitude of consumers shaped by their interaction in social media pages of brands having positive significant effects on purchase intention. So we formulate our fifth hypothesis:

H5: There is a significant association between the attitude of consumers towards brand social media and future purchase intention.

\section{5) E-WORD OF MONTH}

The power of social communication impact through word of mouth has been studied a lot in consumer literature ( Herr, Kardes, \& Kim, 1991; Arndt, 1967). Previous researchers found that WOM considers more persuasive and trustworthy by consumers than conventional media, such as personal selling, TV advertising, radio, and print media. Reviews that are extremely positive increase the attitude toward the brand and on the other hand, review that are moderate negative produce a similar effect. Additionally, strong negative reviews also have a significant effect on attitude toward the brand than either extremely positive or moderate negative reviews (Lee \& Lee, 2009). A huge number of positive reviews have a positive influence on attitude toward the product, purchase intention, and website, however no effects on electronic word of mouth credibility. (Doh \& Hwang, 2009). These different results suggest more research on e-WOM and maybe it involves as a potential mediate variable. (Sharma, Durand, \& Gur-Arie, 1981). Thus, we formulate the hypothesis as follow; 
H6: There is a significant association between e-WOM and future purchase intention.

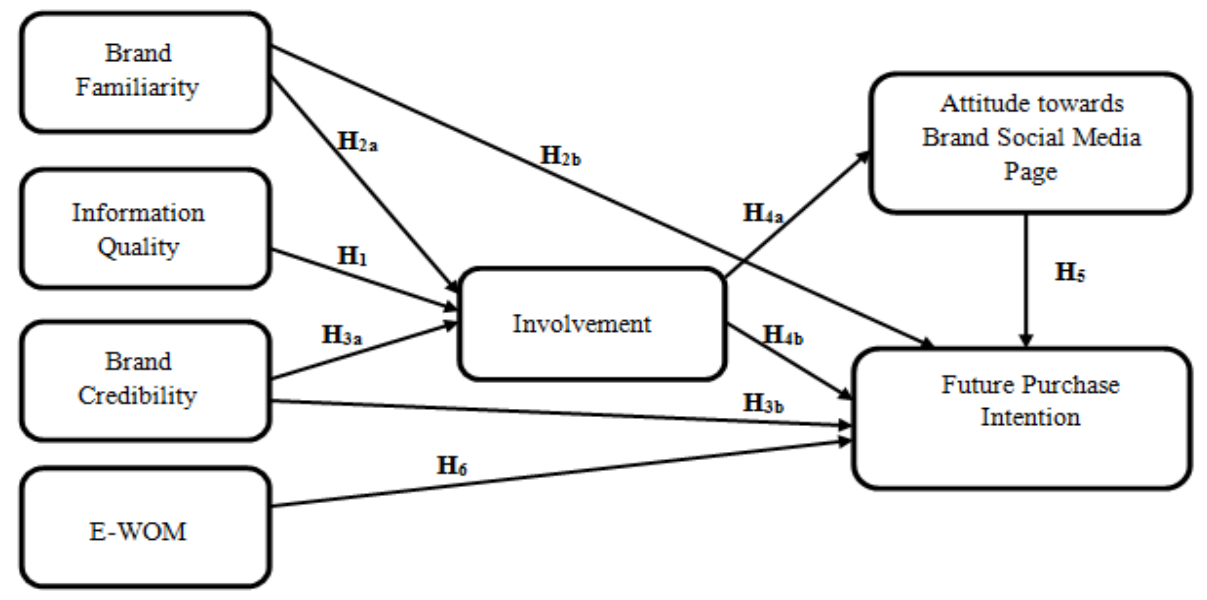

Figure 1: Proposed Study Model

\section{4) METHODOLOGY}

The unit of study is an individual consumer who has experience buying products online. The study mainly focused on consumers of Lahore who are frequently using social media websites. The objective of the study is to inspect the impact of information quality, brand creditability, and brand familiarity, although e- WOM is also an important factor that influences the attitude of consumers towards social media pages of brands and their future purchase intention. We decide to select the Gul Ahmed brand's social media page. Data were collected from the outlet of Gul Ahmed at Emporium Mall and Packages mall and Allama Iqbal town outlet and the number of the respondent were 380 from which we exclude incomplete cases $(n=$ 45 ) and not properly filled response $(n=61)$ and finally, we used 274 responses in our analysis which is $72 \%$ of the total response. To collect data from a sample we design an online survey on goggle form and also collect by hand. A simple random sampling technique was used to collect data.

\section{1) MEASUREMENT DEVELOPMENT}

The questionnaire used a five-point Likert scale and each item was measured from "strongly disagree" to "strongly agree". The survey has two parts. The design of the first part of the questionnaire is to get participants' demographic information, their online buying experience, and the reason for online shopping. The demographic characteristic of respondents survey shows that out of the total respondent $52.6 \%$ were female and $47.4 \%$ male. The age of majority of the male respondent was between 23-25 (50\%) and (36.8\%) female respondents was above 28 above, $21.5 \%$ males were 28 and above, $29.9 \%$ female were between the age group of 23-25, $20 \%$ male were between the age group of $26-28$ and $17.4 \%$ female were between

Page $\mid 16$ 
the age group of $20-22,8.5 \%$ male were between the age group of $20-22$ and $13.9 \%$ female were between the age group of 17-19. The table illustrates that $56.2 \%$ male and $75 \%$ female respondents' reason for online shopping was convenience, $31.5 \%$ male and $20.8 \%$ female said that time-saving, $12.3 \%$ male and $4.2 \%$ female said that product/service not available offline and zero percent said better price. Approximately $53.2 \%$ male and $37.5 \%$ female respondents said that their concerns for shopping online were difficult to evaluate products, $22.3 \%$ male and $23.6 \%$ female were concerns about the delivery time, $20.8 \%$ male and $32.6 \%$ female were lack of trust, $5.6 \%$ female and $0.8 \%$ male were said security concerns and $3.8 \%$ male and $0.7 \%$ female were said privacy concerns. Mostly $56.2 \%$ male and $36.8 \%$ female respondent online shopping experience was $2-3$ times, $29.2 \%$ male was 6-20 times, $10 \%$ male and $9.7 \%$ female were just once and $53.5 \%$ female and $4.6 \%$ male were 21-50 times. Time spend on online shopping per week, approximately $59.2 \%$ male and $38.2 \%$ female participants spent $17-60$ minutes, $52.1 \%$ female and $27.7 \%$ male were spent $1-3$ hours, $13.1 \%$ male and $8.3 \%$ were spent $0-16$ minutes, $1.4 \%$ female was spent more than 3 hours. Money spends on online shopping per year, approximately $70 \%$ male and $31.9 \%$ female participants were spend Rs. 4000 $10,000,28.5 \%$ female and $6.2 \%$ male spend more than Rs. $20,000,28.5 \%$ female and $6.2 \%$ male were spend Rs. $10,000-20,000$ and $11.1 \%$ female and $10.8 \%$ male were spend Rs. Less than Rs.4000. The participants were asked to answer, what product they often purchased from brand Gul Ahmed, mostly $60 \%$ male, and $0.7 \%$ female participants purchased gents shalwar kameez, $51.4 \%$ female and 3.1\% male were purchased ladies dress, $24.3 \%$ female and $10.8 \%$ male were purchased home accessories, $14 \%$ male and $6.3 \%$ female were purchased gents sweater, $17.4 \%$ female and $0.8 \%$ male were purchased ladies bag and $10.8 \%$ male was purchased gents pent shirt. (see Table 1).

The second part of the survey instrument has twenty-four questionnaire items and it measures the seven constructs of the proposed model. All the items were selected from prior related research. To measure these items we adopt the scale of Involvement from (Huang et al. 2010), brand familiarity from (Ha and Perks, 2005; Doong et al. 2011), information quality (Savolainen, 2011), Future purchase intention (Hu et al. 2011), Attitude of consumers towards brand's social media page (Huang et al. 2010), E-Word of mouth (Kim et al. 2011) and Brand credibility from (Erdem et al. 1998).

\section{Table 1 Descriptive Analysis}

\begin{tabular}{|c|c|c|c|}
\hline Measure & Items & Male & Female \\
\hline Gender & Female & 47.4 & 52.6 \\
\hline Age & $17-19$ & 0 & 13.9 \\
\hline & $20-22$ & 8.5 & 17.4 \\
\hline & $23-25$ & 50 & 29.9 \\
\hline & $26-28$ & 20 & 2.1 \\
\hline & 28 and Above & 21.5 & 36.8 \\
\hline
\end{tabular}


IBT Journal of Business Studies (IBT-JBS) Volume 17 Issue 1, 2021

\begin{tabular}{|c|c|c|c|}
\hline $\begin{array}{c}\text { Reason for on Line } \\
\text { Shopping }\end{array}$ & Convenience & 56.2 & 75 \\
\hline & $\begin{array}{l}\text { Service/Product not avail- } \\
\text { able offline }\end{array}$ & 12.3 & 4.2 \\
\hline & Time-Saving & 31.5 & 20.8 \\
\hline \multirow[t]{5}{*}{$\begin{array}{c}\text { Concerns for shopping } \\
\text { online } \\
\end{array}$} & Trust issue & 20.8 & 32.6 \\
\hline & Privacy Issues & 3.8 & 0.7 \\
\hline & Security Issues & 0.8 & 5.6 \\
\hline & Delivery Time Issues & 22.3 & 23.6 \\
\hline & $\begin{array}{l}\text { Difficult to evaluate prod- } \\
\text { ucts online }\end{array}$ & 53.2 & 37.5 \\
\hline \multirow[t]{4}{*}{$\begin{array}{c}\text { Online shopping expe- } \\
\text { rience }\end{array}$} & just once & 10 & 9.7 \\
\hline & 2-3 times & 56.2 & 36.8 \\
\hline & 6-20 times & 29.2 & 0 \\
\hline & $21-50$ times & 4.6 & 53.5 \\
\hline \multirow[t]{4}{*}{$\begin{array}{l}\text { Time spent on online } \\
\text { shopping per week }\end{array}$} & 0-16 minutes & 13.1 & 8.3 \\
\hline & $17-60$ minutes & 59.2 & 38.2 \\
\hline & $1-3$ hours & 27.7 & 52.1 \\
\hline & more than 3 hours & 0 & 1.4 \\
\hline \multirow{4}{*}{$\begin{array}{c}\text { Money spend on online } \\
\text { shopping per year }\end{array}$} & less than 4000 & 10.8 & 11.1 \\
\hline & $4000-10,000$ & 70 & 31.9 \\
\hline & $10,000-20,000$ & 6.2 & 28.5 \\
\hline & More than 20,000 & 13.1 & 28.5 \\
\hline \multirow[t]{6}{*}{$\begin{array}{c}\text { What product they often } \\
\text { purchased from brand } \\
\text { Gul Ahmed }\end{array}$} & Gents shalwar kameez & 60 & 0.7 \\
\hline & Ladies dress & 3.1 & 51.4 \\
\hline & Home accessories & 10.8 & 24.3 \\
\hline & Gents sweater & 14 & 6.3 \\
\hline & Ladies bag & 0.8 & 17.4 \\
\hline & Gents pant shirt & 10.8 & 0 \\
\hline
\end{tabular}




\section{2) RELIABILITY AND VALIDITY OF MEASUREMENT}

The study takes items of the construct from the previous studies, with few slight changes to fit the social media context. Reliability checks through Cronbach's Alpha and cutoff value were (0.7) suggested by (Hair et al. 1988). Four items were selected for brand familiarity shows 0.733 , six items for involvement shows 0.729 , eight items selected for information quality shows 0.898 , five items selected for attitude towards brand social media page shows 0.797 , three-item selected for future purchase intention shows 0.968 , two items selected for e- WOM shows 0.796 and four items for brand credibility shows 0.920 (see Table 2). The cutoff value of CR is 0.7 . The result shows that all CR values off all construct higher than 0.7 , which indicates that convergent validity is established. This shows that the reliability of this model is supported. The values of average variance extracted ranged from 0.66 to 0.977 ; these values were greater than the suggested value of 0.5 , as recommended by Hair et al. (1998).

Furthermore, discriminant validity was also analyzed to check whether a variable is not a reflection of any other variable. According to Fornell and Larcker (1981) suggested that the value of the square root of AVE should be higher than the other coefficient of correlation for acceptable discriminant validity. In table 3 the result shows that the square root of AVE for every construct is higher than the other coefficient of correlation which indicates discriminant validity is established.

Table 2 Cronbach Alpha, Factor Loading and Composite Reliability

\begin{tabular}{|l|l|l|l|c|}
\hline Items & Factor Loading & Cronbach Alpha & $\begin{array}{l}\text { Composite Reli- } \\
\text { ability }\end{array}$ & $\begin{array}{l}\text { Average Variance } \\
\text { Extracted }\end{array}$ \\
\hline Brand Familiarity & & 0.733 & 0.764 & 0.733 \\
\hline bf_1 & .17 & & & \\
\hline bf_2 & .31 & & & \\
\hline bf_3 & .95 & & & \\
\hline bf_4 & .97 & & & \\
\hline Involvement & & 0.729 & 0.719 & 0.66 \\
\hline Invo_1 & .91 & & & \\
\hline Invo_2 & .00 & & & \\
\hline Invo_3 & .04 & & & \\
\hline Invo_4 & .90 & & & \\
\hline Invo_5 & .72 & & & \\
\hline Invo_6 & .94 & & & \\
\hline Information Quality & & 0.898 & & \\
\hline InQ_1 & .79 & & & \\
\hline
\end{tabular}


IBT Journal of Business Studies (IBT-JBS) Volume 17 Issue 1, 2021

\begin{tabular}{|c|c|c|c|c|}
\hline InQ_2 & .66 & & & \\
\hline InQ_3 & .70 & & & \\
\hline InQ_4 & .72 & & & \\
\hline InQ 5 & .92 & & & \\
\hline InQ_6 & .78 & & & \\
\hline InQ 7 & .49 & & & \\
\hline InQ_8 & .82 & & & \\
\hline $\begin{array}{l}\text { Attitude Towards } \\
\text { Brand's Social Me- } \\
\text { dia Page }\end{array}$ & & 0.797 & 0.753 & 0.782 \\
\hline ABSM_1 & .47 & & & \\
\hline ABSM_2 & .90 & & & \\
\hline ABSM_3 & .84 & & & \\
\hline ABSM_4 & .53 & & & \\
\hline ABSM_5 & .40 & & & \\
\hline $\begin{array}{l}\text { Future Purchase In- } \\
\text { tention }\end{array}$ & & 0.968 & 0.855 & 0.977 \\
\hline FPI_1 & .91 & & & \\
\hline FPI_2 & .97 & & & \\
\hline FPI_3 & .99 & & & \\
\hline E-WOM & & 0.796 & 0.779 & 0.906 \\
\hline e-WOM_1 & .95 & & & \\
\hline e-WOM 2 & .70 & & & \\
\hline Brand Credibility & & 0.920 & 0.873 & 0.930 \\
\hline bc_1 & .85 & & & \\
\hline bc_2 & .90 & & & \\
\hline bc_3 & .89 & & & \\
\hline bc_4 & .83 & & & \\
\hline
\end{tabular}

Table 3 Correlation Matrix

\begin{tabular}{|l|r|r|r|r|r|r|l|}
\hline $\begin{array}{l}\text { C o n - } \\
\text { struct }\end{array}$ & ASP & bf & Invo & InQ & EWOM & BC & FPI \\
\hline ASP & 0.867 & & & & & & \\
\hline
\end{tabular}

Page $\mid 20$ 
IBT Journal of Business Studies (IBT-JBS) Volume 17 Issue 1, 2021

\begin{tabular}{|l|l|l|l|l|l|l|l|}
\hline bf & 0.672 & 0.874 & & & & & \\
\hline Invo & 0.581 & 0.438 & 0.847 & & & & \\
\hline InQ & 0.244 & 0.456 & 0.559 & 0.886 & & & \\
\hline EWOM & 0.313 & 0.652 & 0.517 & 0.469 & 0.924 & & \\
\hline BC & 0.452 & 0.467 & 0.459 & 0.578 & 0.589 & 0.882 & \\
\hline FPI & 0.531 & 0.468 & 0.432 & 0.349 & 0.482 & 0.492 & 0.867 \\
\hline
\end{tabular}

\section{5) RESULTS AND ANALYSIS}

In this study, we attempt to establish a relationship between brand familiarity, brand credibility, information quality, and involvement; also this study inspects the association between involvement and future purchase intention of consumers and their attitude towards the social media page of the brand. Further current study; also check the influence of e-WOM on future purchase intention from the brand. The two-step approach, measurement model used for reliability and validity through different methods such as CFA (confirmatory factor analysis) and SEM (structural equation model) employed to test the hypothesis and model fit. To assess the overall model, we test the multicollinearity issues. All values of VIF and Tolerance values (Table 4) were well below 5 and below 10 respectively as suggested by (Hair et al., 1998) that shows that multicollinearity issue does not exist.

Table 4 VIF and Tolerance Values

\begin{tabular}{|c|c|c|c|c|}
\hline Variable & \multicolumn{2}{|c|}{ Attitude Towards brand social media page } & \multicolumn{2}{l|}{ Future Purchase Intention } \\
\hline & Tolerance & VIF & Tolerance & VIF \\
\hline Brand Credibility & .371 & 2.697 & .371 & 2.697 \\
\hline Brand Familiarity & .529 & 1.891 & .529 & 1.891 \\
\hline Information Quality & .915 & 1.093 & .915 & 1.093 \\
\hline Involvement & .456 & 2.192 & .371 & 2.192 \\
\hline
\end{tabular}

\section{1) CONFIRMATORY FACTOR ANALYSIS}

To validate the research model (Table $2 \& 3$ ), CFA (Confirmatory Factor Analysis) was performed by using AMOS software. We did CFA in the study rather than using Exploratory Factor Analysis (EFA), because we derived all of the latent constructs and related measurements from prior research and in the prior study it has shown that their reliability and validity are acceptable. Factor loadings for all variables were greater than 0.54 except BF 1, BF 2, (Brand Familiarity), INV_2, INV_3 (Involvement), IQ 7 (Information Quality) as suggested by (Chin, Gopal, \& Sălisbury, 1997) with no cross construct loadings, shows good discriminant validity. 


\section{2) HYPOTHESIS TESTING}

For analysis, first, we categorized the data into two sub-groups based on gender (male and female). The result of all hypotheses for males and females, separately mention in table 5. To study the association between information quality, brand credibility, and brand familiarity of social media page and involvement of consumers (H1, $\mathrm{H} 2 \mathrm{a}$, and $\mathrm{H} 3 \mathrm{a}$ ), for this information quality, brand familiarity and brand credibility were independent and consumer's involvement was the dependent variable. So the result of path analysis shows that the association between information quality and brand familiarity and involvement was insignificant for both groups. Thus $\mathrm{H} 1$ and $\mathrm{H} 2 \mathrm{a}$ were not supported. While the association between brand credibility and involvement is positively significant at the level of $p$-value $=0.001$ with an estimated value of .531 for the male and .693 for the female group. Thus hypothesis $\mathrm{H} 3 \mathrm{a}$ was supported. The value of model fit of confirmatory factor analysis was GFI 1.000, CFI 1.000, and RMSEA .349 which are above the acceptable limit suggested by (Chau \& Hu, 2001; Bagozzi \& Yi, 1988).

$\mathrm{H} 2 \mathrm{~b}, \mathrm{H} 3 \mathrm{~b}$, and $\mathrm{H} 6$, of the study, are that brand familiarity, brand credibility, and e-WOM have a positive association with future purchase intention. Based on path analysis brand familiarity is positively significant related to future purchase intention at the level of $1 \%$ with an estimated value of .369 for males while female analysis shows negative significant relation at the level of $1 \%$ with an estimated value (-.178). Brand credibility also found a positive significant association with future purchase intention at the level o $1 \%$ with an estimated value .527 and 1.034 for the male and female groups respectively. Further e-wom shows a positive significant association with future purchase intention at the level of $1 \%$ with an estimated value .423 in the male group while in the female group, interestingly it shows a negative significant with an estimated value (-.140).

To determine the association between social media involvement and future purchase intention $(\mathrm{H} 4 \mathrm{a})$ and the association between attitude towards social media appearance and future purchase intention (H5). The result shows that a positive significant relationship association was found between involvement and future purchase intention with an estimated value of .465 for males and .353 for the femalE group. Consumers' attitudes towards social media pages found a positive significant association with future purchase intention with an estimated value of .329 for male and .476 for female group. Further, (H4b) of the study is that the association between involvement and consumers' attitude towards social media pages. The findings show that a positive significant association exists between involvement and consumers' attitude towards social media pages with an estimated value of .619 for male and .586 for female group. 
IBT Journal of Business Studies (IBT-JBS) Volume 17 Issue 1, 2021

Table 5: Path Coefficients

\begin{tabular}{|c|c|c|c|c|c|}
\hline Hypothesis & \multicolumn{2}{|c|}{ Male } & \multicolumn{2}{|c|}{ Female } & \multirow[t]{2}{*}{ Results } \\
\hline & Estimates & Significance & Estimate & Significance & \\
\hline $\mathrm{H}_{1}$ & .008 & .891 & -0.16 & .791 & NOT SUPPORTED \\
\hline $\mathrm{H}_{2 \mathrm{a}}$ & .258 & .003 & .080 & .257 & NOT SUPPORTED \\
\hline $\mathrm{H}_{3 \mathrm{a}}$ & .531 & 0.001 & .693 & 0.001 & SUPPORTED \\
\hline \multicolumn{6}{|c|}{ MoDEL FIT $=G F I=1.000, C F I=1.000, R M S E A=.349$} \\
\hline $\mathrm{H}_{2 \mathrm{~b}}$ & .369 & 0.001 & -.178 & 0.001 & SUPPORTED \\
\hline $\mathrm{H}_{3 \mathrm{~b}}$ & .527 & 0.001 & 1.034 & 0.001 & SUPPORTED \\
\hline $\mathrm{H}_{6}$ & .423 & 0.001 & -.140 & .002 & $\begin{array}{c}\text { SUPPORT FOR MALE } \\
\text { BUT NOT SUPPORT- } \\
\text { ED FOR FEMALE }\end{array}$ \\
\hline \multicolumn{6}{|c|}{ MODEL FIT $=G F I=1.000, C F I=1.000, R M S E A=.529$} \\
\hline $\mathrm{H}_{4 \mathrm{~b}}$ & .465 & 0.001 & .353 & 0.001 & SUPPORTED \\
\hline $\mathrm{H}_{5}$ & .329 & 0.001 & .476 & 0.001 & SUPPORTED \\
\hline \multicolumn{6}{|c|}{ MODEL FIT $=G F I=1.000, C F I=1.000$, RMSEA $=.445$} \\
\hline $\mathrm{H}_{4 \mathrm{a}}$ & .619 & 0.001 & .586 & 0.001 & SUPPORTED \\
\hline
\end{tabular}

\section{6) DISCUSSION AND CONCLUSION}

Consumer purchase intention is currently an important topic to research because most of the population has an online shopping experience. The major objective of the study was to inspect the factors of future purchase intention. Also, we studied the relationship of involvement on social media with an attitude towards the social media page of a brand and future purchase intention. Further, also examine the association between e-WOM and consumers' future purchase intention from the brand. The outcomes proposed important implications for operators of social media websites, online advisers, and interactive marketing practitioners. Also, the contribution of our results to the literature of consumer behavior in the academic world is that social media involvement is becoming more relevant in consumer shopping and purchase behavior and can significantly impact attitude toward brand or firm.

The findings of this study found that both had great brand credibility did positively significantly affect the involvement of consumers on social media pages, while the brand familiarity and information quality were not turned into significant. Furthermore, the findings showed that the involvement of consumers with a brand on social media is a noteworthy factor in facilitating and forming the attitude towards the social media page of the brand, which directs to future purchase intention of the 
consumers for both group male and female. These findings are in line with (Davis Mersey, Malthouse, \& Calder, 2010).

Interestingly, the results of this study revealed that information quality and brand familiarity of a brand had no significant effect than brand credibility on being involved with brands' social media pages. Brand credibility was found to be positive significantly affects the future purchase intention of a brand for both groups while brand familiarity was found to be a negative significant association with future purchase intention for female group but found positive significant for male group. This means that the brand which is more credible and familiar shows higher future purchase intention towards the brand. This result is consistent with the previous studies (Erdem \& Swait, 2004).

Our results recommend that brand familiarity may have primarily prompted an individual to search for social media page of a brand. So, while familiarity may attract consumers to the social media page of the brand, the credibility of brand plays an important role in increasing the involvement of consumers in the brand's social media page. This result is similar to previous studies that have found a significant relationship between brand credibility, brand familiarity, and involvement (Yang, 2012).

Further, study found that involvement on the social media page of a brand positive significantly associated with attitude towards the social media page of a brand for both groups. This connection follows from prior work that has found the association between attitude and involvement (Bosnjak, Galesic, \& Tuten, 2007; Huang, Chou, \& Lin, 2010; Schivinski \& Dabrowski, 2016). The results showed that positive significant relation exists between e-wom and future purchase intention for male while found negative significanT for female group. This result is similar to prior studies such as (Erkan \& Evans, 2016). Social media platforms are significant for marketers they owe to the huge numbers of users; furthermore, these websites are deemed very suitable platforms for e-WOM (Canhoto \& Clark, 2013). So this is the reason, factors presented by the current study are important in sense of practicality. It helps the marketers to know the importance of e-WOM on social media, also, to build up better marketing strategies. Our study also revealed that attitude towards brand social media pages was associated with the future purchase intention. From this result, we recommended that firms should be mainly focused on content on their social media page like that to leads high involvement on social media page which would affect future purchase intention and also that it would be essential for social media page to contain web links with all details about where and how to purchase as well as be prepared to answers the user's questions regarding making a future purchase from the brand.

\section{1) LIMITATION AND FUTURE DIRECTION}

The results of this study are significant and add to the existed pool of literature and contribute to the knowledge regarding e-WOM, future purchase intention, and incremental effect of involvement and attitude of social media pages of the brand, but this study also has some limitations. We did not add in few control variables such as brand image, brand prestige, and usage experience, which may become the Page $\mid 24$ 
possible factors influencing the brand purchase intention. Moreover, in this study we limited our respondents; by recalling consumers on a specific brand on social media we did not consider the consumers of other brands. Future studies should examine the comparative study between other brands, and make a comparison of the relative strengths of the relation among brand image, brand credibility, brand awareness, and brand purchase intention.

Finally, the consumer doing online shopping may belong to different cultural backgrounds, have different mindsets, and their intention of shopping may also not be the same. To investigate those cultural differences and their intention of online shopping, consider customers living in other provinces of Pakistan and make a comparison of the impact of those cultural differences on the model and their intentions of online shopping.

Authorship(s) validation: The authors have no financial or proprietary interests in any material discussed in this article.

\section{REFERENCES}

Aladwani, A. M., \& Palvia, P. C. (2002). Developing and validating an instrument for measuring user-perceived web quality. Information \& Management, 39(6), 467-476.

Alhidari, A., Iyer, P., \& Paswan, A. (2015). Personal level antecedents of eWOM and purchase intention, on social networking sites. Journal of Customer Behaviour, $14(2), 107-125$.

Arndt, J. (1967). Role of product-related conversations in the diffusion of a new product. Journal of marketing Research, 4(3), 291-295.

Bagozzi, R. P., \& Yi, Y. (1988). On the evaluation of structural equation models. Journal of the academy of marketing science, 16(1), 74-94.

Barreda, A. A., Bilgihan, A., Nusair, K., \& Okumus, F. (2015). Generating brand awareness in online social networks. Computers in human behavior, 50, 600609

Canhoto, A. I., \& Clark, M. (2013). Customer service 140 characters at a time: The users' perspective. Journal of marketing Management, 29(5-6), 522-544.

Chatterjee, P. (2001). Online reviews: do consumers use them?

Chau, P. Y., \& Hu, P. J. H. (2001). Information technology acceptance by individual professionals: A model comparison approach. Decision sciences, 32(4), 699719.

Chin, W. W., Gopal, A., \& Salisbury, W. D. (1997). Advancing the theory of adaptive structuration: The development of a scale to measure faithfulness of appropriation. Information systems research, 8(4), 342-367. 
Christodoulides, G., Jevons, C., \& Bonhomme, J. (2012). Memo to marketers: Quantitative evidence for change: How user-generated content really affects brands. Journal of advertising research, 52(1), 53-64.

Davis Mersey, R., Malthouse, E. C., \& Calder, B. J. (2010). Engagement with online media. Journal of Media Business Studies, 7(2), 39-56.

Doh, S.-J., \& Hwang, J.-S. (2009). How consumers evaluate eWOM (electronic word-of-mouth) messages. CyberPsychology \& Behavior, 12(2), 193-197.

Erdem, T., \& Swait, J. (2004). Brand credibility, brand consideration, and choice. Journal of consumer research, 31(1), 191-198.

Ergin, E. A., \& Akbay, H. O. (2010). Consumers Purchase Intentions For Foreign Products: An Empirical Research Study In Istanbul, Turkey. International Business \& Economics Research Journal (IBER), 9(10).

Fornell, C., \& Larcker, D. F. (1981). Evaluating structural equation models with unobservable variables and measurement error. Journal of marketing research, $18(1), 39-50$

Hair, J. F., Black, W. C., Babin, B. J., Anderson, R. E., \& Tatham, R. L. (1998). Multivariate data analysis (Vol. 5): Prentice hall Upper Saddle River, NJ.

Herr, P. M., Kardes, F. R., \& Kim, J. (1991). Effects of word-of-mouth and productattribute information on persuasion: An accessibility-diagnosticity perspective. Journal of consumer research, 17(4), 454-462.

Jahn, B., \& Kunz, W. (2012). How to transform consumers into fans of your brand. Journal of Service Management.

Jain, S., \& Mishra, S. (2018). Effect of value perceptions on luxury purchase intentions: an Indian market perspective. The International Review of Retail, Distribution and Consumer Research, 28(4), 414-435.

Jalilvand, M. R., \& Samiei, N. (2012). The effect of electronic word of mouth on brand image and purchase intention: An empirical study in the automobile industry in Iran. Marketing Intelligence \& Planning.

King, C. W., \& Summers, J. O. (1970). Overlap of opinion leadership across consumer product categories. Journal of marketing Research, 7(1), 43-50.

Lee, J., \& Lee, J.-N. (2009). Understanding the product information inference process in electronic word-of-mouth: An objectivity-subjectivity dichotomy perspective. Information \& Management, 46(5), 302-311.

Lenhart, A., Purcell, K., Smith, A., \& Zickuhr, K. (2010). Social Media \& Mobile Internet Use among Teens and Young Adults. Millennials. Pew internet \&

Page $\mid 26$ 
American life project.

Lohse, G. L., \& Spiller, P. (1998). Electronic shopping. Communications of the ACM, 41(7), 81-87.

Martins, J., Costa, C., Oliveira, T., Gonçalves, R., \& Branco, F. (2019). How smartphone advertising influences consumers' purchase intention. Journal of Business Research, 94, 378-387.

Nam, K., Baker, J., Ahmad, N., \& Goo, J. (2020). Determinants of writing positive and negative electronic word-of-mouth: Empirical evidence for two types of expectation confirmation. Decision Support Systems, 129, 113168.

Saima, \& Khan, M. A. (2020). Effect of social media influencer marketing on consumers' purchase intention and the mediating role of credibility. Journal of Promotion Management, 27(4), 503-523.

Shareef, M. A., Mukerji, B., Dwivedi, Y. K., Rana, N. P., \& Islam, R. (2019). Social media marketing: Comparative effect of advertisement sources. Journal of Retailing and Consumer Services, 46, 58-69.

Sharma, S., Durand, R. M., \& Gur-Arie, O. (1981). Identification and analysis of moderator variables. Journal of marketing Research, 18(3), 291-300.

Wang, A., \& Lin, C. (2011). Effects of content class with endorsement and information relevancy on purchase intention. Management Research Review.

Wang, S. W., Kao, G. H.-Y., \& Ngamsiriudom, W. (2017). Consumers' attitude of endorser credibility, brand and intention with respect to celebrity endorsement of the airline sector. Journal of Air Transport Management, 60, 10-17.

Watts, S. A., \& Zhang, W. (2008). Capitalizing on content: Information adoption in two online communities. Journal of the association for information systems, 9(2), 3 . 